\title{
Motivace pro nasazení Free Software GIS ve výuce geoinformatiky
}

\author{
Martin Landa \\ Department of Mapping and Cartography \\ Faculty of Civil Engineering, CTU in Prague \\ E-mail: martin.landa@fsv.cvut.cz
}

\begin{abstract}
Abstrakt
Cilem tohoto př́spěvku je prezentovat využití svobodného softwaru při výuce na studijním oboru Geodézie a kartografie $\check{C} V U T$ v Praze a předevšim motivaci pokračovat v tomto trendu při výuce geoinformatiky a to $v$ souvislosti s novým oborem na ČVUT - Geoinformatikou. Současně jsou v textu nastíněny základni aspekty výuky GIS s důrazem na volně širitelné nástroje a geoprostorová data. Na závěr jsou zmíněny praktické zkušenosti s nasazením svobodného softwaru na cvičeních $k$ předmětu Zpracováni obrazových dat.
\end{abstract}

\section{Dosavadní využití GNU nástrojů na studijním oboru Geodézie a kartografie}

GNU aplikace (či obecně programy s otevřeným zdrojovým kódem) mají v učebním procesu (viz studijní plán [6]) na oboru $\mathrm{G}+\mathrm{K}$ (Geodezie a kartografie) poměrně bohatou historii. V tomto ohledu nelze ani v nejmenším opomenout zásluhy prof. Aleše Čepka - bez jeho nasazení by zcela jistě $\mathrm{k}$ něčemu podobnému vůbec nedošlo.

V rámci předmětu Informatika 1 se studenti seznamují s operačním systém (OS) GNU/Linux. Je poměrně zajímavé, že se právě zde viditelně profilují nadprůměrní studenti. Tento předmět je nosný pro celou řadu dalších předmětů. Jde především o povinné předměty Informatika 2 a 3, kde se vyučují základy programovaní v jazyce $\mathrm{C}++$. Výuka na cvičeních potom probíhá pod OS GNU/Linux, studenti běžně pracují s textovým editorem GNU Emacs ${ }^{1}$, kompilátorem GNU $\mathrm{g}++^{2}$ a ve výjimečných př́padech i s debuggerem GNU gdb ${ }^{3}$ (či s $\mathrm{DDD}^{4}$ ). Dále se využívá programový balík GNU Octave ${ }^{5}$ pro řešení výpočetně náročných úloh v rámci předmětu Vyšší geodézie.

Vedle OS GNU/Linux, sady nástrojů pro programování (textový editor, kompilátor, debugger) a programu GNU Octave primárně určeného pro numerické výpočty se pod hlavičkou předmětu Zpracování obrazových dat [8] využívá GRASS GIS ${ }^{6}$. V současnosti je to pravděpodobně jediný svobodný GIS software, který se na oboru $G+K$ při výuce používá.

\footnotetext{
${ }^{1}$ http://www.gnu.org/software/emacs

${ }^{2}$ http://gcc.gnu.org

${ }^{3}$ http: //www . gnu.org/software/gdb

${ }^{4}$ http://www.gnu.org/software/ddd

${ }^{5}$ http://www.gnu.org/software/octave

${ }^{6}$ http://grass.itc.it
} 


\section{Svobodný software jako jeden z pilířů studijního plánu oboru Geoinforma- tika}

V zimním semestru 2006/2007 se otevírá na FSv ČVUT nový bakalářský studijní obor Geoinformatika. O rok později bude nastartován navazující magisterský studijní obor. O motivaci pro otevření tohoto oboru na ČVUT blíže pojednává [1]. Po bližším prostudování doporučeného studijního plánu [7] je poměrně zřetelná spojitá linie předmětů s důrazem na svobodný software a jeho využití v praxi.

Studijní obor Geoinformatika stojí na pevně definovaných pilî́ŕch - teoretické geodézii, katastru nemovitostí a především informatice jako takové. Geoinformatika je totiž především geoprostorově orientovanou informatikou, na výuku informatiky by tak měly být kladeny ty nejvyšší požadavky. Při sestavování studijního plánu byl na tento fakt kladen co možná největší dưraz.

Omezíme-li se na informatické předměty související s osvětou v oblasti svobodného softwaru - v prvním semestru si studenti osvojí základy práce s OS GNU/Linux, v rámci předmětu Algoritmy a základy numerické matematiky bude využit s největší pravděpodobností programovací jazyk Python ${ }^{7}$. V druhém semestru se studenti blíže seznámí s architekturou a návrhem databázových systémů s důrazem na relační DBMS, na cvičeních bude primárně využit PostgreSQL ${ }^{8}$. Studenti tak získají nutný základ pro absolvování navazujících předmětů (GIS druhé a třetí generace, geodatabáze, programovaní pro DBMS, webové mapové služby, atd.).

Jednou ze základních dovedností absolventa technického oboru by měla být schopnost aplikovat jednoduché programovací techniky (např. skriptování). To bohužel mnohdy neplatí, v případě studenta oboru geoinformatika je neznalost programování zcela zásadní, téměř diskvalifikační. Proto je na programovaní ve studijních plánech kladen tak velký důraz. Základní programovací aparát studenta oboru Geoinformatika budou tvořit jazyky C++, Java a Python (tj. hybridní objektově orientované programovací jazyky).

Student magisterského oboru si dokonce může zapsat i předmět, který se orientuje čistě na svobodný software v geoinformatice - povinně volitelný Free Software GIS.

\section{Role svobodného softwaru při výuce GIS}

Vedle obecně rozššřených proprietárních systémů hraje Free Software / Open Source Software významnou roli při adaptaci technologie GIS. Poskytuje přístup k technologii uživatelům, kteří si z nejrůznějších důvodů nemohou dovolit používat proprietární systémy. Navíc rozmanitost v přístupu k vývoji softwaru je zásadní pro pokračující inovaci v oblasti geoinformačních technologií.

Model vývoje svobodného softwaru přináší velmi důležitý aspekt - potřebu komunikace a to jak v rámci komunity jako takové, tak i mimo ni - v širším kontextu. Dokladem toho je právě vzniknuvší nadace pro podporu Open Source GIS ${ }^{9}$.

\footnotetext{
${ }^{7}$ http: //www.python.org

${ }^{8}$ http: //www.postgresql.org

${ }^{9}$ http: //www.osgeo.org
} 
Vedle svobodného softwaru nelze opomenout důležitost volně dostupných geoprostorových dat. Zatímco v U.S.A. je celá škála geodat poskytována zcela zdarma, v Evropě tomu tak není, ba naopak v této oblasti zde existují poměrně značné restrikce. Tento restriktivní přistup neoddiskutovatelně brání dalšímu vývoji a výrazně znesnadňuje dostupnost informací. V Evropě bohužel neexistuje tradice volného sdílení výsledků nejrůznějších projektů a to nejen z oblasti GIS.

Problematika dostupnosti geodat by měla být předmětem veřejné diskuze a to zejména s ohledem na zdroje volně dostupných dat. Vedle možnosti volně používat software stojí potřeba svobodné datové základny. Postupné doplňování výchozího datasetu na cvičeních GIS z dalších (on-line 'public domain') datových zdrojů lze považovat za pozitivní prŕnos studijního procesu.

Jeden z dalších motivačních aspektů může být zapojení studentů do vývoje softwaru (na nejrůznějších úrovních). Otevírá se tak cesta k řešení nejrůznějších projektů a možnosti prezentovat jejich výsledky samotnými studenty nejen v České republice, ale i v mezinárodním měřítku.

Vedle obecných základů GIS by se měli studenti seznámit jak s proprietárními, tak otevřenými programovými systémy. Svobodný software by měl být podporován a rozšiřován právě na akademické půdě.

\section{GRASS GIS jako nástroj pro zpracování obrazových dat}

GRASS GIS se úspěšně používá od akademického roku 2003/2004 na cvičeních k předmětu Zpracování obrazových dat [8]. Pro jeho nasazení hovořilo hned několik důvodi̊, zejména licenční problémy s doposud používaným proprietárním softwarem.

$\mathrm{Na}$ začátku tohoto akademického roku byla nově spuštěna GeoWikiCZ ${ }^{10}$ - jako nástroj pro prezentaci studijního programu $\mathrm{G}+\mathrm{K}$ (který v současné době pokrývá dva studijní obory Geodézii a kartografii a nově i Geoinformatiku). O motivaci a zkušenostech s využití wiki jako nástroje pro skupinovou správu webových stránek s ohledem na akademické prostředí blî̌ze pojednává [3]. Když během minulého zimního semestru vznikaly návody na cvičení $\mathrm{k}$ předmětu Zpracování obrazových dat, nebylo pochyb, kam tyto texty umístit - na GeoWikiCZ.

Tématické zaměření bylo v podstatě převzato z předchozích semestrů:

- seznámení s architekturou GISu GRASS, základní terminologie, vizualizace dat

- základní metody zvýraznění obrazu

- roztažení histogramu

- barevné syntézy, modely barev RGB a IHS

- mapová algebra

- filtrace obrazu

- import/export dat, georeferencování obrazových dat

- Fourierova transformace

${ }^{10}$ http://gama.fsv.cvut.cz 
- ř́zená a neřízená klasifikace obrazových dat

Jako datový podklad byl použit z větší části dataset z minulého akademického roku, doplněný o několik datových vrstev z datasetu FreeGeodataCZ ${ }^{11}$. Jednou z úloh, kterou studenti řešili, byl import souřadnicově připojených a nepřipojených obrazových dat. Základní družicová scéna pokrývající zájmové území (severozápadní Čechy) LandSat5-TM z roku 1994 tak byla doplněna o snímek z nosiče LandSat7-ETM+ (2004) a LandSat1-MSS (1975), viz obr.1.

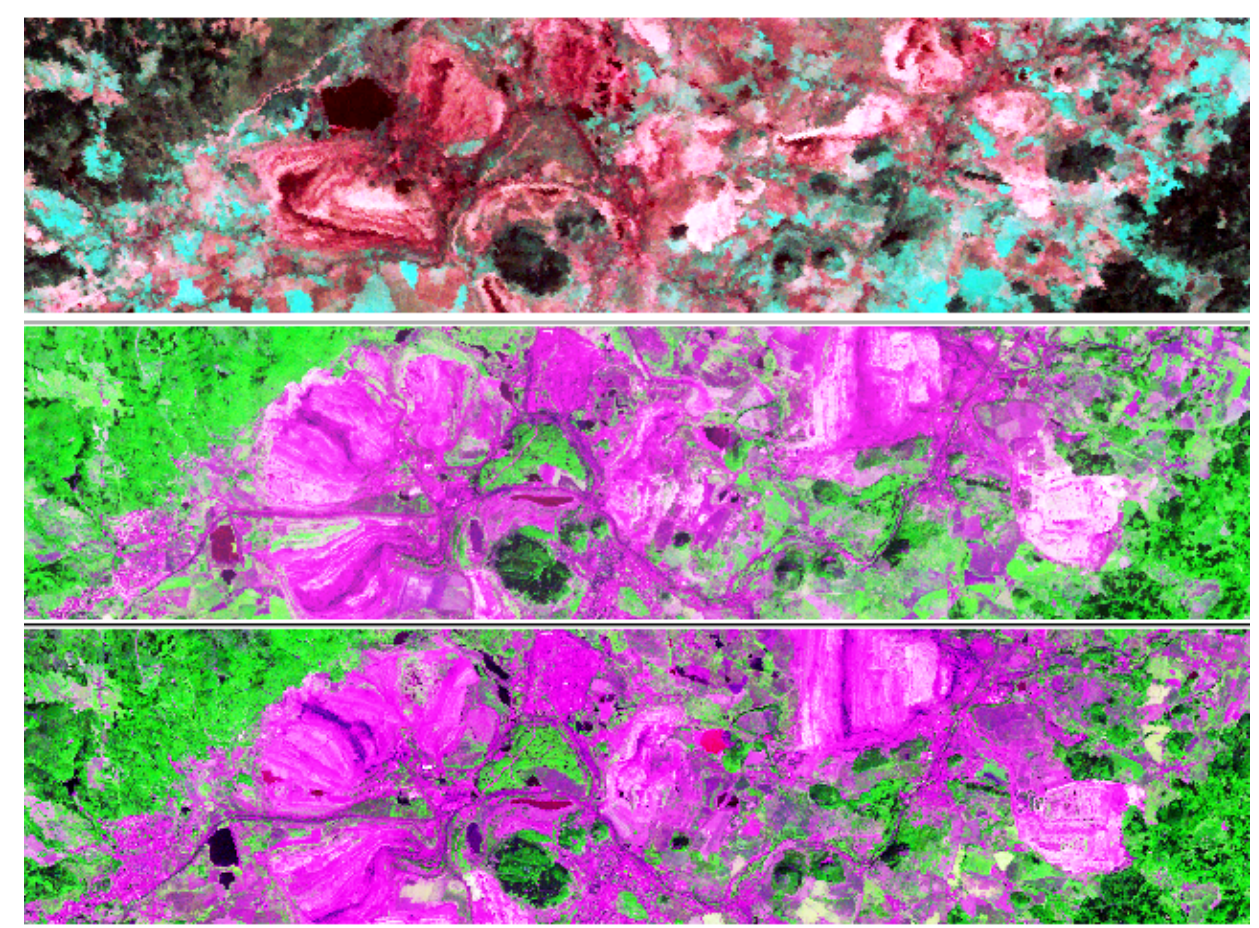

Obr č.1: RGB barevná syntéza 243: LandSat MSS (1975), TM (1994), ETM+ (2004)

Příprava učebního textu podobného rozsahu sebou přináší vedle pozitivních i mírně negativní dopady. Studenti jistě ocenili možnost se předem připravit na dané cvičení. Na druhou stranu byla u některých studentů znatelná tendence typu zkopírovat př́kaz z webové stránky do př́kazové konzole, spustit jej a o nic víc se nestarat. Takových jedinců však byla menšina a i oni dříve nebo později narazili na problém, který byli nuceni řešit.

Bylo potěšující a do jisté míry zcela jistě motivující sledovat zanícení a odborný růst studentů. První kroky v GRASSu, potažmo v OS GNU/Linux (drtivá většina z nich totiž neabsolvovala Informatiku 1 ve stávající podobě, s OS GNU/Linux se tedy setkali v mnoha př́ípadech poprvé v životě) jistě nebyly jednoduché či snadné. Na posledních cvičeních byli téměř všichni schopni pracovat v prostředí GRASSu bez znatelnějších problémů. Ba dokonce někteří ze studentů projevili zájem si nainstalovat GRASS přímo na svém osobním počítači.

Bylo by škoda nezmínit i další fakt. Během výuky se narazilo na řadu softwarově orientovaných problému či nedostatků a to jak ze strany studentů, tak vyučujícího. Tyto nedostatky pomalu ale jistě autor článku řeší. To lze považovat svým zpơsobem za přínosné - používámeli při výuce svobodný software, v podstatě nic nám nebrání nalezené nedostatky či chyby

\footnotetext{
${ }^{11}$ http://grass.fsv.cvut.cz/wiki/index $. p h p /$ Geodata_CZ
} 
odstraňovat a přispět tak ke zkvalitnění celého softwarového projektu.

\section{Plány do budoucna}

Během přípravy na zimní semestr 2006/2007 se počítá s poměrně výrazným rozšǐrením učebního textu, a to jak s ohledem na GRASS GIS, tak na ostatní programové nástroje z rodiny svobodného softwaru. Půjde pravděpodobně o Open Source Software Image Map ${ }^{12}$ (OSSIM) a balík pro statistické výpočty $\mathrm{R}^{13}$.

\section{Závěr}

Svobodný software má jistě v učebním procesu na vysokých školách svoje pevné místo. V mnoha př́padech je možnost studovat zdrojový kód (tj. detailní znalost jak je daná úloha přesně řešena) velmi potřebná až téměř nezastupitelná.

Výuka geoinformatiky by měla být obecně orientována na standardy a jejich prosazování. Projekty řešené na akademické půdě by měly být $\mathrm{v}$ ideálním př́ípadě zaměřeny na volně šiřitelný software a jeho další zdokonalování. V žádném případě nelze omluvit využití státních dotací v souvislosti s uzavřenými, silně komerčními systémy.

\section{Reference}

1. Leoš Mervart and Aleš Čepek. Geoinformatics Study at the Czech Technical University in Prague ${ }^{14}$. In From Pharaohs to Geoinformatics (FIG Working Week 2005 and GSDI8). Fédération Internationale des Géomètres (International Federation of Surveyors), April 16-21, Cairo, Egypt 2005

2. M. Landa. GRASS jako pomůcka při výuce GIS a DPZ ${ }^{15}$. In Konference GIS Ostrava 2005, 23.-26. ledna 2005.

3. J. Pytel and M. Landa. Možnosti systému wiki při správě informačních zdrojů ${ }^{16}$. In Belcom 06, 6.-7. února 2006.

4. J. Nieminen. Teaching Gis The Gnu Way. In Open Source Free Software GIS - GRASS users conference 2002, Trento, Italy, 11-13 September 2002

5. Mitasova Helena, Neteler Markus. Freedom In Geoinformation Science And Software Development: A Grass Gis Contribution ${ }^{17}$. In Open Source Free Software GIS - GRASS users conference 2002, Trento, Italy, 11-13 September 2002

\footnotetext{
${ }^{12}$ http: //WwW.ossim.org

${ }^{13}$ http: //www.r-project.org

${ }^{14}$ http://geoinformatika.fsv.cvut.cz/2005/ap-2005-mervart-cepek/ap-2005-mervart-cepek.pdf

${ }^{15}$ http://gamam.fsv.cvut.cz/cgi-bin/viewcvs.cgi/*checkout*/publications/2005/gis_ostrava_05/ ref_grass_go05.pdf?root=cvs_landa

${ }^{16}$ http://gamam.fsv.cvut.cz/cgi-bin/viewcvs.cgi/*checkout*/publications/2006/belcom_06/ pytel-landa_wiki.pdf?rev=1.1\&root=cvs_landa

${ }^{17}$ http://www.ing.unitn.it/ grass/conferences/GRASS2002/proceedings/proceedings/pdfs/ Mitasova_Helena_3.pdf
} 
6. Doporučený studijní plán oboru Geodézie a kartografie

7. Doporučený studijní plán oboru Geoinformatika

8. Návody na cvičení k předmětu Zpracování obrazových dat 